УДК 16.89-008.454+616.8-009.836.14

DOI 10.11603/bmbr.2706-6290.2021.1.12097

Л. Г. Кутузова ${ }^{1,2}$, М. I. Марущак ${ }^{2}$

КНП «Клінічний пологовий будинок Пресвятої Діви Марії» ${ }^{1}$

Тернопільський національний медичний університет імені I. Я. Горбачевського МОЗ України

\title{
СОН ЯК РЕГУЛЯТОР ЗДОРОВ’Я ОРГАНІЗМУ
}

\section{Сон як регулятор здоров'я організму}

\section{л. Г. Кутузова ${ }^{1,2}$, М. І. Марущак ${ }^{2}$}

КНП «Клінічний пологовий будинок Пресвятої Діви Марії»» Тернопільський національний медичний університет імені І. Я. Горбачевського мОЗ України²

Резюме. Сон є важливим фрізіологічним процесом, тому його порушення негативно впливає на фрізичне та психологічне здоров'я. В останні роки сонливість та проблеми зі сном є ендемічними серед населення.

Мета дослідження - проаналізувати сучасні дані щодо фрункції сну в нормі та за умови порушень сну.

Матеріали і методи. Для реалізації поставленої мети було проаналізовано наукову літературу за останнє десятиліття, які доступні у мережі «Internet», ключовими словами були «фрункції сну», «порушення сну».

Результати. Відновлення сну асоціюється з поліпшенням фрізичних, когнітивних та психологічних показників. Під час сну відбуваються множинні процеси росту та гомеостазу. Сон також впливає на імунні процеси. Адаптивні імунні клітини відіграють значну роль у пластичності мозку. Так само імунні клітини важливі для загоєння ран та ангіогенезу. Підвищений рівень циркулюючого кортизолу, пов'язаний з недосипанням, пов'язаний із запізненням загоєння ран та підвищеним ризиком тяжкої інфрекції. Гормон росту та секреція пролактину збільшуються під час сну для сприяння анаболізму протеїнів. I навпаки, підвищення рівня продукції кортикостероїдів, пов'язане з недосипанням, пов'язане з катаболізмом протеїнів та збільшенням витрат енергії. Нейрокогнітивні та психологічні процеси зростають під час сну. На кодування та консолідацію пам'яті впливає порушення сну. Сон відіграє роль в афрективній реактивності, яка також модулює пам'ять. Достатній сон необхінний для процесів пам'яті, які часто страждають при неврологічних захворюваннях та травмах. Особи, які мають розлади сну, також мають підвищений ризик депресії. Порушення сну та психічні розлади мають двосторонні взаємозв'язки. Скорочена тривалість сну асоціюється з підвищеним ризиком летального наслідку від ішемічної хвороби серця або інсульту.

Висновки. Порушення сну часто виникають у результаті захворювань організму, що, у свою чергу, веде до поглиблення розладів сну.

Ключові слова: сон; розлади; захворюваність.
Sleep as a regulator of the body health

L. G. Kutuzova ${ }^{1,2}$, M. I. Marushchak ${ }^{2}$

Clinical Maternity Hospital of the Blessed Virgin Mariya ${ }^{1}$

I. Horbachevsky Ternopil National Medical University ${ }^{2}$

e-mail: marushchak@tdmu.edu.ua

Summary. Sleep is an important physiological process, so its violation negatively affects physical and psychological health. In recent years, drowsiness and sleep problems have been endemic among the population.

The aim of the study - to analyze current data on sleep function in normal and sleep disorders.

Materials and Methods. To achieve this goal, the scientific literature for the last decade, which is available on the Internet, was analyzed, the key words were "sleep functions", "sleep disorders".

Results. Restoration of sleep is associated with improved physical, cognitive and psychological performance. During sleep, multiple processes of growth and homeostasis occur. Sleep also affects immune processes. Adaptive immune cells play a significant role in brain plasticity. Immune cells are also important for wound healing and angiogenesis. Elevated circulating cortisol associated with sleep deprivation is associated with delayed wound healing and an increased risk of severe infection. Growth hormone and prolactin secretion are increased during sleep to promote protein anabolism. Conversely, the increase in corticosteroid production associated with sleep deprivation is associated with protein catabolism and increased energy expenditure. Neurocognitive and psychological processes increase during sleep. Coding and memory consolidation are affected by sleep disturbances. Sleep plays a role in affective reactivity, which also modulates memory. Adequate sleep is necessary for memory processes, which often suffer from neurological diseases and injuries. People with sleep disorders are also at increased risk for depression. Sleep disorders and mental disorders have a two-way relationship. Shortened sleep duration is associated with an increased risk of death from coronary heart disease or stroke.

Conclusions. Sleep disorders often occur as a result of diseases of the body, which, in turn, leads to a deepening of sleep disorders.

Key words: sleep; disorders; morbidity. 


\section{ВСТУП}

Сон $є$ важливим фрізіологічним процесом, тому його порушення негативно впливає на орізичне [1] та психологічне здоров'я [2]. В останні роки сонливість та проблеми зі сном $є$ ендемічними серед населення [3]. В останні роки сонливість та проблеми зі сном $є$ ендемічними серед населення [3]. Приблизно третина дорослого населення має певні форми порушення сну. Окремі дослідження продемонстрували, що вік, стать, соціально-економічний статус, спосіб життя, надмірне використання смарторонів та психологічний стан $€$ фракторами ризику порушення сну [4-7]

Метою дослідження було проаналізувати сучасні дані щодо функції сну в нормі та за умови порушень сну.

\section{МАТЕРІАЛИ I МЕТОДИ}

Для реалізації поставленої мети було проаналізовано наукову літературу за останнє десятиліття, які доступні у мережі «Internet», ключовими словами були «фрункції сну», «порушення сну».

\section{РЕЗУЛЬТАТИ Й ОБГОВОРЕННЯ}

Регуляція сну зосереджена в гіпоталамусі, який контролює складні взаємодії нейромедіаторів, які стимулюються світлом, мелатоніном та нервовими шляхами [8]. Сон - це фрізіологічний стан, що складається 3 двох ключових фаз: нешвидкого руху очей (NREM) та швидкого руху очей (REM). Сон NREM складається з легкого сну, помірного сну та глибокого сну [9]. REM вважається найбільш відновлювальною фразою сну. Здорові люди проходять через фрази NREM та REM кілька разів протягом ночі, кожен цикл триває 90-100 хв [8, 10]. При цьому часті переривання сну, такі, як при госпіталізації, при чергуванні медперсоналу, гальмують справжній спокійний сон $[10,11]$.

Загальновідомо, що сон відіграє роль у фрізичному, когнітивному та психологічному самопочутті. До недавнього часу фрункції сну були в основному теоретичними, теорії переважно зосереджувались на адаптації та відновленні. Моделі на тваринах показали, що сон не є виключно відновним або ж адаптивним. На експериментальній моделі Aton et al. [12] визначили, що сон необхідний для консолідації пам'яті. Xie et al. [13] відкрили механізм, за допомогою якого мозок відновлюється від токсичного інтерстиційного «сміття» під час сну. Без сну, пам'ять зазнала б негативного впливу, а нейротоксини зруйнували б мозок.

Відновлення сну асоціюється з поліпшенням фрізичних, когнітивних та психологічних показників [14]. Під час сну відбуваються множинні процеси росту та гомеостазу. Сон також впливає на імунні процеси. Клітинний імунітет і функція ци- токінів змінюються при порушенні сну $[8,15,16]$. Адаптивні імунні клітини відіграють значну роль у пластичності мозку [17]. Так само імунні клітини важливі для загоєння ран та ангіогенезу. Підвищений рівень циркулюючого кортизолу, пов'язаний 3 недосипанням, пов'язаний із запізненням загоєння ран та підвищеним ризиком тяжкої інсрекції [18]. McGonigal [19] описав фрункції ендокринної системи під час сну. Вісь гіпоталамус-гіпофріз-щитоподібна залоза важлива для срізичного відновлення. Гормон росту та секреція пролактину збільшуються під час сну для сприяння анаболізму протеїнів. I навпаки, підвищення рівня продукції кортикостероїдів, пов'язане $з$ недосипанням, пов'язане 3 катаболізмом протеїнів та збільшенням витрат енергії [8]. Нейрокогнітивні та психологічні процеси зростають під час сну. Дослідження на експериментальних тваринах показали, що сон модулює нейропластичність [20]. На кодування та консолідацію пам'яті впливає порушення сну. Сон відіграє роль в афеективній реактивності, яка також модулює пам'ять $[21,22]$. Достатній сон необхідний для процесів пам'яті, які часто страждають від неврологічних захворюваннях та при травmax.

Результати дослідження порушень та розладів сну дають деяке розуміння впливу сну на фрізичні, когнітивні та психологічні симптоми. Експериментальні дослідження показали, що відсутність сну швидше призводить до летального результату, ніж голодування [14]. Обмеження сну в людей корелює 3 низкою когнітивних процесів. Ferrara et al. [23] вивчали обмеження сну серед студентів і визначили, що сон відіграє важливу роль у запам'ятовуванні та просторовому навчанні. У дослідженні Lo et al. пильність i тривала увага були когнітивними сферами, на які найбільше впливає порушення сну [24]. Подібні висновки також повідомляли Valenza et al. [18], який заявив, що на пам'ять, словесне навчання, увагу та прийняття рішень впливають порушення сну. Mellman [25] стверджує, що розлади сну сприяють розвитку стійкого посттравматичного стресового розладу. Особи, які мають розлади сну, також мають підвищений ризик депресії [26]. Порушення сну та психічні розлади мають двосторонні взаємозв'язки, про що свідчать більш високі показники розладів сну в осіб із психіатричними та психологічними захворюваннями [27]. Біль і сон також мають зворотний взаємозв'язок: посилення болю призводить до погіршення сну, що, у свою чергу, веде до посилення болю $[18,27]$. Pywell [28] зазначає, що скорочена тривалість сну асоціюється з підвищеним ризиком летального наслідку від ішемічної хвороби серця або інсульту. Особи, які працюють по змінах, мають підвищений ризик серцево-судинних та 
шлунково-кишкових захворювань [29]. Також існує думка, що ці особи мають більший ризик розвитку раку молочної залози, цукрового діабету 2 типу та патологій вагітності. Для змінних працівників також $€$ характерним високий рівень виробничого травматизму внаслідок порушення сну.

\section{REFERENCES}

1. Morovatdar N, Ebrahimi N, Rezaee R. Sleep duration and risk of atrial fibrillation: a systematic review. Journal of atrial Fibrillation. 2019;11(6): 2019.

2. Newman B, Enright PL, Manolio TA. Sleep disturbance, psychosocial correlates, and cardiovascular disease in 5201 older adults: the Cardiovascular Health Study. Journal of the American Geriatrics Society. 1997;45(1): 1-7.

3. Ferrara M, De Gennaro L. How much sleep do we need? Sleep Medicine Reviews. 2001;5(2): 155-79.

4. Ohayon MM, Zulley J. Correlates of global sleep dissatisfaction in the German population. Sleep. 2001;24(7): 780-7.

5. Nojoumi M, Ghalehbandi M, Kafashi S. Sleep pattern in medical students and residents. Archives of Iranian Medicine. 2009;12(6): 542-9.

6. Bixler EO, Kales A, Soldatos CR. Prevalence of sleep disorders in the Los Angeles metropolitan area. The American Journal of Psychiatry. 1979;136(10): 1257-62.

7. Demirci K, Akgönül M, Akpinar A. Relationship of smartphone use severity with sleep quality, depression, and anxiety in university students. Journal of Behavioral Addictions. 2015;4(2): 85-92.

8. Kamdar BB, Needham DM, Collop NA. Sleep deprivation in critical illness: Its role in physical and psychological recovery. Journal of Intensive Care Medicine. 2012;27(2): 97-111. DOI: 10.1177/0885066610394322

9. Berger AM. Update on the state of the science: Sleep wake disturbances in adult patients with cancer. Oncology Nursing Forum. 2009;36(4): E165-E177. DOI:10.1188/09

10. Matthews EE. Sleep disturbances and fatigue in critically ill patients. AACN Advances in Critical Care. 2011;22(3): 204-24. DOI: 10.1097/NCl.0b013e31822052cb

11. Bihari S, McEvoy RD, Matheson E. Factors affecting sleep quality of patients in intensive care unit. Journal of Clinical Sleep Medicine. 2012;8(3): 301-7. Available from: http://www.aasmnet.org/jcsm/

12. Aton SJ, Suresh A, Broussard C. Sleep promotes cortical response potentiation following visual experience. Sleep. 2014;37(7): 1163-70.

13. Xie L, Kang $H, X u$ Q. Sleep drives metabolite clearance from the adult brain. Science. 2013;342: 373-7.

14. Brand S, Kirov R. Sleep and its importance in adolescence and in common adolescent somatic and psychiatric conditions. International Journal of General Medicine. 2011;4: 425-42. DOI: 10.2147/IJGM.S11557

15. Faraut B, Boudjeltia KA, Vanhamme L. Immune, inflammatory and cardiovascular consequences of sleep restriction and recovery. Sleep Medicine Reviews. 2012;16(2): 137-49. DOI: 10.1016/j.smrv.2011.05.001

\section{висновки}

Отримані дані свідчать про те, що фрізіологічний сон забезпечує фрізичне й психологічне здоров'я. Порушення сну часто виникають в результаті захворювань організму, що, у свою чергу, веде до поглиблення розладу сну.

16. Maurovich-Horvat E, Pollmacher T, Sonka K. The effects of sleep and sleep deprivation on metabolic, endocrine and immune parameters. Prague Medical Report. 2008;109(4): 275-85. Available from: http://pmr. cuni.cz/journalhome-1308

17. Schwartz M, Kipnis J, Rivest S. How do immune cells support and shape the brain in health, disease, and aging? The Journal of Neuroscience. 2013;33(45): 1758796. DOI: 10.1523/NEUROSCI.3241-13.2013

18. Valenza MC, Rodenstein DO, Fernandez-de-lasPenas C. Consideration of sleep dysfunction in rehabilitation. Journal of Bodywork and Movement Therapies. 2011;15(3): 262-7. DOI: 10.1016/j.jbmt.2010.07.009

19. McGonigal KS. The importance of sleep and the sensory environment to 57 critically ill patients. Intensive Care Nursing. 1986;2(2): 73-83.

20. Dash MB, Douglas CL, Vyazovskiy VV. Long term homeostasis of extracellular glutamate in the rat cerebral cortex across sleep and waking states. Journal of Neuroscience. 2009;29(3): 620-9.

21. Walker MP. The role of sleep in cognition and emotion. Annals of the New York Academy of Science. 2009;1156: 168-97. DOI: 10.1111/j.1749- 6632.2009.04416.x

22. Zunzunegui C, Gao B, Cam E. Sleep disturbance impairs stroke recovery in the rat. Sleep. 2011;34(9): 12619.

23. Ferrara M, laria G, Tempesta D. Sleep to find your way: The role of sleep in the consolidation of memory for navigation in humans. Hippocampus. 2008;18(8): 844-51.

24. Lo JC, Groeger JA, Santhi N, et al. Effects of partial and acute total sleep deprivation on performance across cognitive domains, individuals and circadian phase. PLoS ONE. 2012;7(9): e445987.

25. Mellman TA. A human model that suggests a role for sleep in the cognitive neuropsychology of PTSD and recovery. Sleep. 2009;32(1): 9-10.

26. AlDabal L, BaHammam AS. Metabolic, endocrine, and immune consequences of sleep deprivation. Open Respiratory Medicine Journal. 2011;5: 31-43.

27. Dogan O, Ertekin S, Dogan S. Sleep quality in hospitalized patients. Journal of Clinical Nursing. 2005;14: 107-3.

28. Pywell A. Promoting sleep in neurorehabilitation patients: Theory and practice. British Journal of Neuroscience Nursing. 2013;9: 16-21.

29. Harma M. Work hours in relation to work stress, recovery, and health. Scandinavian Journal of Work, Environment and Health. 2006;32(6): 502-14.

Отримано 06.03.21
ISSN 2706-6282(print)

ISSN 2706-6290(online)
Вісник медичних і біологічних досліджень

Bulletin of Medical and Biological Research 